\title{
Richness and biomass distribution of the mangrove macroalgal association in a subtropical estuary
}

\author{
Inara Regina Wengratt Mendonça ${ }^{1, *(\infty)}$, Paulo da Cunha Lana ${ }^{1}$
}

\begin{abstract}
'Universidade Federal do Paraná, Centro de Estudos do Mar, Laboratório de Bentos (Av. Beira-mar, s/n, Pontal do Paraná, Paraná, Brasil, Zipcode: 83255-976).

* Corresponding author: inara.regina@gmail.com
\end{abstract}

\begin{abstract}
The richness and biomass distribution of mangrove macroalgae were evaluated along the main salinity gradient of the Paranaguá Bay subtropical estuarine complex in southern Brazil. We used a spatially hierarchical design to investigate the spatial scales that contributed most to the variation in richness and biomass within the association. A total of eighteen taxa of macroalgae and cyanobacteria were identified with nonlinear patterns of distribution. While richness correlated with the salinity gradient, algal biomass did not follow the predicted pattern. Conversely, most of the mangrove macroalgae distribution patterns were more related to small-scale processes than to salinity variation. These results indicated that even though coastal regions are exposed to large-scale environmental processes, the somewhat disregarded small-scale processes should be also considered to unravel patterns in biological distributions.
\end{abstract}

Descriptors: Bostrychia, Salinity gradient, Hierarchical sampling, Spatial scales.

\section{INTRODUCTION}

Mangrove trees support diverse macroalgal associations attached to their branches, roots and pneumatophores in intertidal and subtidal regions (Dawes et al. 1999; Zhang et al. 2014). This unique association of macroalgae was named Bostrychietum by Post (1936), referring to Bostrychia-Caloglossa associations. These associations include other genera of red algae, cyanobacteria and Chlorophyta (Pedroche et al. 1995). Although Bostrychietum is commonly identified in mangroves, it can also be found in salt marshes and sheltered habitats in temperate regions (Sluiman, 1978; Reine and Marchand, 1983).

Submitted: 10-Feb-2021

Approved: 04-Oct-2021

Associate Editor: Karen Diele

() 2021 The authors. This is an open access article distributed under the terms of the Creative Commons license.
Coastal macroalgae provide essential ecosystem services such as blue carbon sequestration (Hill et al. 2015); along with seagrass, mangrove macroalgae represent more than $50 \%$ of the carbon food source for polychaetes, crabs and oligochaetes (Kieckbusch et al. 2004). Bostrychietum itself is the main refuge for invertebrates, such as bivalves, acari, nematodes and terrestrial insects; therefore, it is essential for maintaining mangrove fauna diversity (Heithaus et al. 2011; Vieira et al. 2018).

Studies worldwide have investigated the main scales of spatial and seasonal variations in mangrove macroalgae species in estuarine environments (Fernandes et al. 2005, Melville et al. 2005, Peña-Salamanca 2008, Billah et al. 2016). Salinity gradients play an important role as a source of variability in mangrove macroalgae, causing the species distribution to change within estuaries (Yarish and Edwards 1982, Yokoya et al. 1999; Cunha and Costa 
2002, Steinke et al. 2003, Fernandes et al. 2005). In a Brazilian estuary where the horizontal salinity gradient ranges from 0 to 30, species richness increased towards euhaline water (Cunha and Costa 2002). On the other hand, salinity did not affect species distribution in an Australian estuary, where the salinity range is less pronounced (10 to 20) (Melville and Pulkownik 2007).

Macroalgae tolerance to salinity is species-specific based on their physiological responses (Karsten, 2012). For example, under osmotic stress conditions, to maintain constant turgor pressure, species from the genus Caloglossa (Delesseriaceae) biosynthesize and accumulate the organic osmolyte mannitol (Karsten et al. 1992). According to species tolerance characteristics, they can be classified as euryhaline, referring to broad halotolerance, or stenohaline species, with a narrow range of salinity tolerance.

Describing the distribution area of algae species along a salinity gradient is facilitated by using a hierarchical sampling design. Hierarchical designs are essential to properly understand organism-environment relationships given the intrinsically scaledependent patterns in nature (Horne \& Schneider 1995). For example, the density of the crab Ucides cordatus is not affected by large-scale processes such as horizontal salinity gradients but rather by its patchy distribution at smaller scales (Sandrini-Neto \& Lana 2012). In contrast, fauna associated with kelp forests responded to sea surface temperature patterns on a large scale $(200 \mathrm{~km})$ as well as to smaller scale processes $(1-65 \mathrm{~km}$ ) due to unknown factors (Lamy et al. 2018). Therefore, without properly addressing the involved spatial scales, we can infer incorrect distribution patterns or disregard small-scale interactions between associations, their environment, and biological traits responsible for structuring them (McGarigal et al. 2016).

Our study investigates how Bostrychietum algae distribution changes along an estuarine horizontal salinity gradient and within haline sectors. Changes were measured through macroalgal species richness, biomass, and patterns of association in mangroves from Paranaguá Bay in southern Brazil. We tested the hypothesis that the salinity gradient is a major driver of the Bostrychietum algae spatial distribution by increasing richness, biomass, and overall changes with increasing salinity.

\section{METHODS}

\section{STUdY SITE}

Paranaguá Bay, Paraná, in southern Brazil (Figure 1), has a subtropical climate, with an average annual precipitation of approximately $2,500 \mathrm{~mm}$. The water temperature in summer and winter ranges from $23-30^{\circ} \mathrm{C}$ and $18-25^{\circ} \mathrm{C}$, respectively, and the tidal cycle is semidiurnal, with a mean tidal range of 2.2 $\mathrm{m}$ (Lana et al. 2001). The water salinity ranges from 0 to 35 , and the salinity gradient allows for the division of the bay into at least three haline sectors. The sectors are oligohaline (mean salinity of 15), mesohaline (mean salinity of 23) and euhaline (mean salinity of 27) (Lana et al. 2001; Marone et al. 2005). This estuary is also characterized by an energy gradient going from high-energy in the euhaline sector, to low-energy in the oligohaline sector (Lana et al. 2001). Throughout the sectors, the mangrove forests can be mono- or multispecific and composed of Rhizophora mangle L. (Rhizophoraceae), Avicennia schaueriana Stapf \& Leechman ex Moldenke (Acanthaceae) and Laguncularia racemosa (L.) C. F. Gaertn (Combretaceae).

\section{SAMPLING DESIGN}

To study the spatial variation in the macroalgae association, we used a hierarchical design including two spatial scales of variation: sectors and areas (Figure 1). The minimum distance between sectors was $10 \mathrm{~km}$ (S1-Oligohaline, S2-Mesohaline and S3Euhaline). Nested into sectors there were areas (A1, $A 2$ and A3). The distance between areas within a single sector ranged between 1 and $5 \mathrm{~km}$. Within each area, macroalgae were scraped from three tree stem surfaces, regardless of tree species. Trees were 1 to 5 $\mathrm{m}$ distant from each other. Sampling was performed at the mangrove fringe away from tidal river mouths to avoid freshwater discharge (Lana et al., 2001). Two sampling campaigns were carried out, totaling 54 samples. Sampling campaigns were performed at the end of winter (05 October 2011) and at the end of summer (04 April 2012) and were analyzed individually due to lack of seasonal replication.

\section{Field AND LABORATORY PROCEDURES}

The upper vertical limit of distribution of Bostrychietum algae coincides with mean high tides 


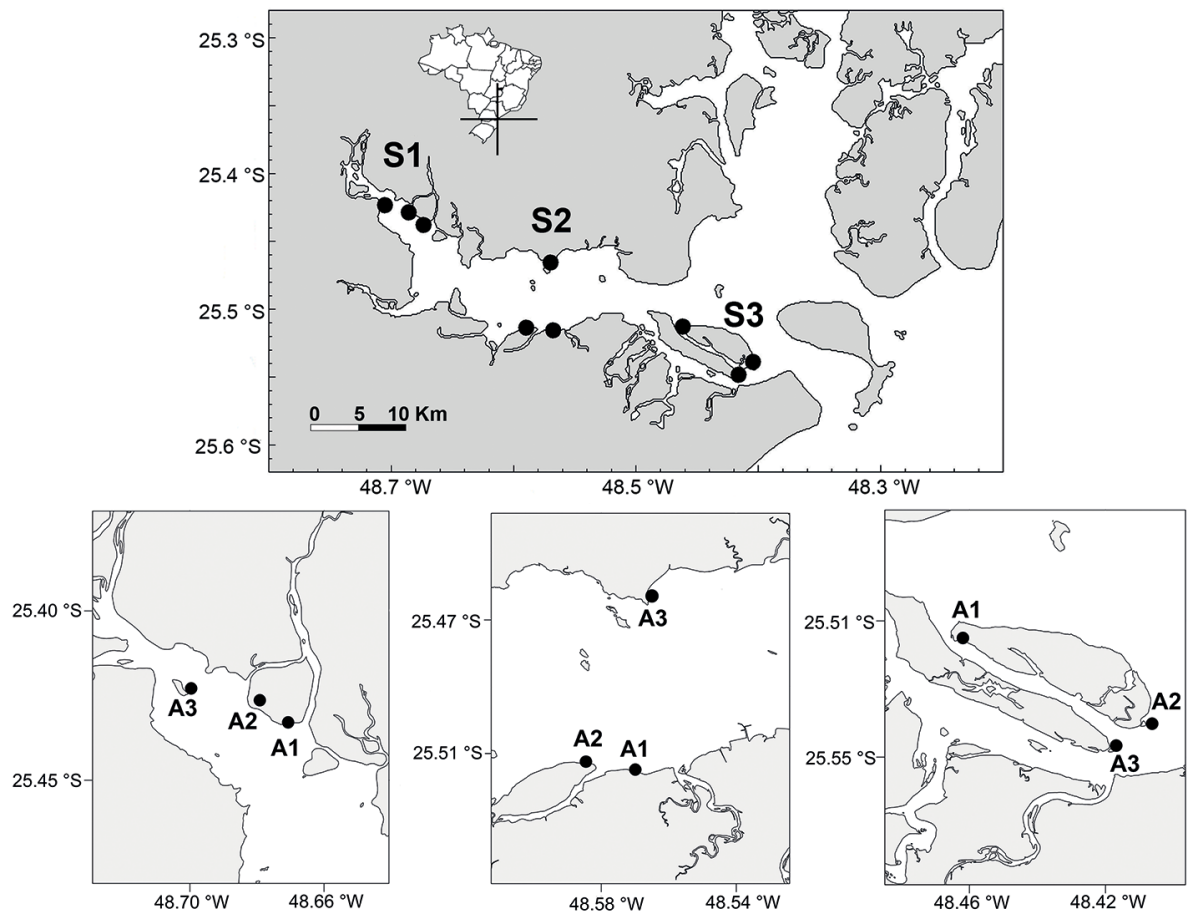

Figure 1. Paranaguá Bay with sectors (S1-Oligohaline, S2-Mesohaline and S3-Euhaline) and areas within sectors (dark circles) where samples were collected. Map source GSHHG database version 2.3.7 from 2017 (Wessel \& Smith, 1996).

in Paranaguá Bay. In the euhaline sector, spring tide is approximately $1.7 \mathrm{~m}$, and the upper limit ofBostrychietum algae is approximately $0.5 \mathrm{~m}$, while in the oligohaline sector, spring tide builds up to $2.7 \mathrm{~m}$, and upper limit is approximately $1 \mathrm{~m}$ (in relation to mean sea level) (Lana et al. 2001, Spier et al. 2016). Therefore, we used the upper vertical limit as an indicator of mean high tides, and standardized sampling 20-40 $\mathrm{cm}$ below this level; we thus reduced the variability in tidal elevation and algal desiccation frequency. The sampled area was calculated by multiplying 20 $\mathrm{cm}$ (vertical stem length being sampled) by tree stem diameter. The material was preserved in $4 \%$ formaldehyde until further processing.

In the laboratory, the algae were rinsed with freshwater, and the attached sediment was removed with brushes. Taxonomic identification followed Joly (1957, 1965, 1967), Cordeiro-Marino (1978), Hadlich \& Bouzon (1985) and updates from Collado-Vides \& West (1996), Cunha et al. (1999), West et al. (2001) and Alves et al. (2009), alongside information from the online database AlgaeBase (Guiry \& Guiry, 2020). After identification, the material was rinsed one last time with freshwater to remove any residue and dried in a Thermo Scientific oven at $60^{\circ} \mathrm{C}$ until a stable mass was achieved. The dry weight of each species was determined using a balance with a precision of $0.001 \mathrm{~g}$. Biomass values of Chlorophyta were below the scale detection limit, so we pooled all species together to obtain biomass data for the whole group.

\section{Data ANALysis}

To identify the overall patterns in Bostrychietum algae along the salinity gradient, we explored algae richness, total biomass, and the most abundant species. Total biomass data were based on the algal biomass $\left(\mathrm{mg} \mathrm{cm}^{-2}\right.$ ) of each tree, regardless of algae species. Next, we identified the most abundant species of algae ( $>10 \mathrm{mg} \mathrm{cm}^{-2}$ ) in the entire estuary ( 5 species in total). Richness and biomass means are reported with standard errors.

Spatial variability of richness, total biomass and most abundant species data were tested using nested ANOVA with fixed (sectors) and random factors (areas and replicates) in a balanced design. Prior to statistical tests, normality and homoscedasticity assumptions were verified using Shapiro-Wilk and Cochran's $C$ tests, respectively, accepted for $\mathrm{P}$ > 
0.05 . When ANOVA results indicated significant differences, Student-Newman-Keuls post hoc analysis (SNK) was performed testing paired means. Cochran's test, nested ANOVA and SNK post hoc analysis were performed using the GAD package (Sandrini-Neto \& Camargo, 2020). The percentage of contribution (PC\%) was calculated using the function VarCorr from the Ime4 package (Bates et al. 2015) and added to ANOVA tables. All statistics in this study were performed in $\mathrm{R}$ version 4.0.2 (R Core Team, 2020).

The Bostrychietum algae were evaluated as associations using multivariate analyses of association biomass and association composition. Association biomass takes into consideration the biomass data from each individual algae species identified (10 species in summer, 9 species in winter and the pooled Chlorophyta). Due to the high abundance of null values, the association biomass data were transformed to $\log (x+1)$, followed by PERMANOVA analysis based on the Bray-Curtis dissimilarity matrix (9999 permutations). The association biomass data were then transformed into presence/absence data for association composition analysis using PERMANOVA based on the Jaccard dissimilarity matrix (9999 permutations). Homoscedasticity of association biomass and composition data was checked with function betadisper, and PERMANOVAs were executed using adonis (model: matrices $\sim$ sector + area:sector), both from vegan package (Oksanen, 2020). In case of significant differences, post hoc tests were performed using the pairwise.adonis function from the pairwiseAdonis package (Arbizu, 2017).

We applied non-Metric Multidimensional Scaling (nMDS) to the abovementioned distance matrices (Bray-Curtis and Jaccard) to visualize the spatial distance among samples. The nMDSs were generated using the metaMDS function from the vegan package (try=150) (Oksanen, 2020). The stress value is reported as an indicator of how well the data distribution represents the real distance among samples (< 0.1 good, $>0.2$ random ordination (Clarke, 1993)).

\section{RESULTS}

\section{Spatial VARiation - TAXa}

A total of sixteen species of macroalgae and two genera of cyanobacteria were identified (Table 1).
The mean richness per sample was $7.7 \pm 0.30$ and 6.6 \pm 0.33 in summer and winter, respectively (Figure 2). In the summer campaign, the mean richness values were different among sectors (Table 2). Richness was higher at S3 $(9 \pm 0.7)$ than at S1 and S2 $(6 \pm 1$ and $7 \pm$ 1 , respectively) (SNK, $\mathrm{P}<0.05)$. Among areas, richness means were different within S1 and S3 (SNK, $\mathrm{P}<0.05)$. In the winter campaign, richness was similar between sectors (S1: 6, S2: 6, S3: 7) and varied within S1 and S3, with mean richness ranging from 5 to 11 taxa per sample (SNK, $\mathrm{P}<0.05)$.

The association composition based on presence/ absence data varied at all spatial scales in both sampling campaigns (Table 2). The post hoc test was unable to detect the source of variation among areas. However, it showed differences among sectors (PERMANOVA, $\mathrm{P}<0.001$ ), and these differences can be visualized through the absence overlap of $S 3$ with other sectors on the nMDS ordination plot (Figure 3A).

\section{Spatial VARIATION - BIOMASS}

The biomass data analyzed here belong to 10 species of Rhodophyta in the summer and 9 in the winter, plus the pooled Chlorophyta biomass, without distinction of species or genera. Individual Chlorophyta species and Canistrocarpus cervicornis biomass were below the scale detection limit. The outcome of the association biomass PERMANOVA analysis showed significant variation along the estuarine gradient in both sampling campaigns (Table 3). The nMDS ordination indicated $\mathrm{S} 3$ as being the most clearly separated from the others. The areas within S3 were not clearly separated in the nMDS plot; however, within $\mathrm{S} 1$ and $\mathrm{S} 2$, areas were grouped (PERMANOVA, $\mathrm{P}<$ 0.001) (Figure 3B, Table 3).

The mean total biomass was $6.3 \pm 0.59 \mathrm{mg} \mathrm{cm}^{-2}$ and $7 \pm 0.66 \mathrm{mg} \mathrm{cm}^{-2}$ for winter and summer, respectively. There was a tendency of increase in total biomass towards higher salinities in winter and more evidently so in summer when biomass values were 2.2 times higher in S3 than in S1 (S1: 4, S2: 7, S3: 9 mg $\mathrm{cm}^{-2}$ ). This tendency was driven by high biomass of $B$. montagnei and $B$. binderi in $\mathrm{S} 3$ and their null values in S1 (Figure 4). However, a statistical test did not identify biomass mean value differences, probably due to differences in biomass among areas in $\mathrm{S} 3$ in both campaigns (SNK, $\mathrm{P}<0.05$ ). 


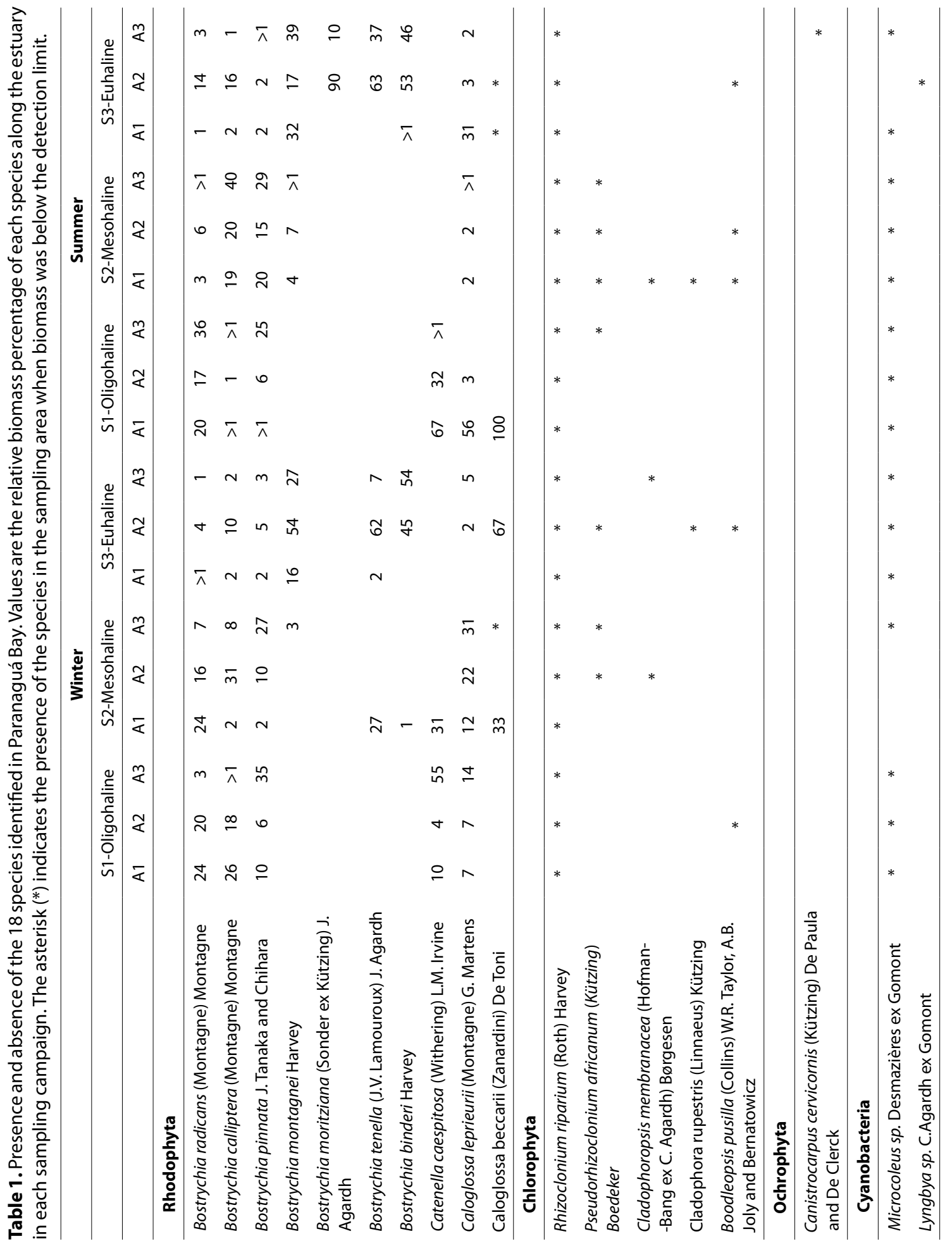




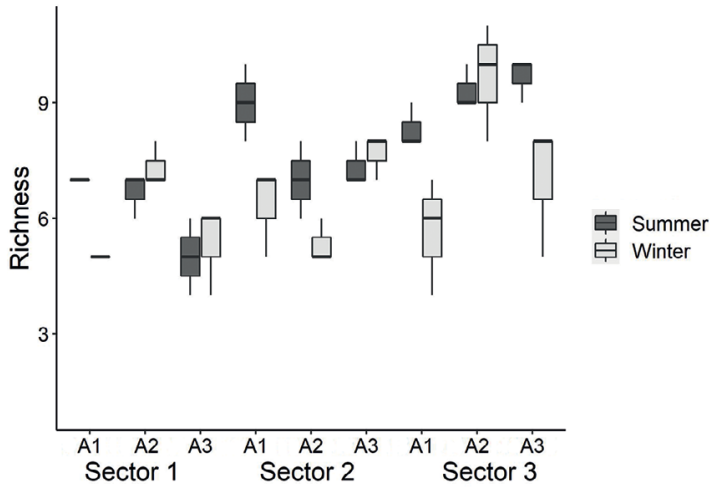

Figure 2. Boxplot of the richness of taxa identified along the estuarine gradient. Winter (gray) and summer sampling campaign (black).

The overall most abundant species were $B$. radicans, B. pinnata, B. montagnei, B. calliptera and B. binderi, all of which had a total biomass above $10 \mathrm{mg}$ $\mathrm{cm}^{-2}$ (Figure 4). The testing of the ANOVA assumptions for these species resulted in heteroscedasticity in B. montagnei, B. pinnata, and B. radicans biomass data, requiring fourth root transformation to reduce the heterogeneity of the variances in both sampling campaigns. Furthermore, B. calliptera data were square root transformed in winter and fourth root transformed in summer. B. calliptera data (winter) and B. montagnei data (summer) were not normally distributed even after data transformation. None of the requirements could be reached for $B$. binderi (both sampling campaigns) and B. montagnei (winter campaign). Given the general robustness of ANOVA against non-normality and heterogeneity of variance under balanced designs (Underwood 1997), we opted for doing the analyses but lowered the significance level from 0.05 to 0.01 (Underwood 1997).

Bostrychia radicans was present throughout the estuarine gradient, however, it had higher biomass in $\mathrm{S} 1$ (SNK, $\mathrm{P}<0.05$ ). Bostrychia pinnata was also present at all sampling sites, and its biomass varied within sectors rather than among sectors. In contrast, B. montagnei and B. binderi biomasses were higher in S3 than in the other sectors. Although the B. binderi and $B$. montagnei distribution patterns were similar, B. montagnei biomass was higher in $\mathrm{S} 3$ in both campaigns, while $B$. binderi had higher biomass only in the summer campaign (Table 3 ). The statistical analysis of B. calliptera biomass data had inconclusive outcomes. Significantly different mean values were identified among areas in winter and among sectors in summer.

\section{DISCUSSION}

Our working hypothesis was partially refuted. Although the richness and composition of Bostrychietum algae correlated positively with the salinity gradient, algal biomass did not follow this pattern and did not vary significantly on a larger spatial scale. The richness associated with hard substrate provided by regional mangroves was in fact influenced by the estuarine salinity gradient, with a greater richness in S3, a tendency even more evident in the summer campaign. The association composition

Table 2. Summary of statistical analyses applied to taxon data. Richness was analyzed with nested ANOVA. Association composition (presence/absence) was analyzed with a PERMANOVA, for which $\mathrm{R}^{2}$ values are shown. (df: degrees of freedom; MS: Mean of Squares; F: (random nested factor corrected by residuals), R2: Correlation, PC\%: Percentage of Contribution). P. value < alpha level in bold.

\begin{tabular}{|c|c|c|c|c|c|c|c|c|c|c|}
\hline \multirow[b]{2}{*}{ ANOVA } & \multicolumn{5}{|c|}{ Winter } & \multicolumn{5}{|c|}{ Summer } \\
\hline & $\mathrm{df}$ & MS & $\mathrm{F}$ & PC\% & $P$ & $\mathrm{df}$ & MS & $\mathrm{F}$ & PC\% & $P$ \\
\hline \multicolumn{11}{|l|}{ Richness } \\
\hline Sector & 2 & 5.60 & 0.79 & 0 & 0.497 & 2 & 18.81 & 6.77 & 46 & 0.028 \\
\hline Area & 6 & 7.11 & 5.65 & 55 & 0.001 & 6 & 2.78 & 5.36 & 30 & 0.002 \\
\hline Residuals & 18 & 1.26 & & 45 & & 18 & 0.51 & & 25 & \\
\hline PERMANOVA & df & MS & $\mathrm{F}$ & $\mathrm{R}^{2}$ & $P$ & $\mathrm{df}$ & MS & $\mathrm{F}$ & $\mathrm{R}^{2}$ & $P$ \\
\hline \multicolumn{11}{|l|}{$\begin{array}{l}\text { Association } \\
\text { composition }\end{array}$} \\
\hline Sector & 2 & 0.52 & 8.35 & 31 & $<0.001$ & 2 & 0.88 & 28.12 & 60 & $<0.001$ \\
\hline Area & 6 & 0.20 & 3.25 & 36 & $<0.001$ & 6 & 0.10 & 3.28 & 21 & $<0.001$ \\
\hline Residuals & 18 & 0.06 & & 33 & & 18 & 0.31 & & 19 & \\
\hline
\end{tabular}



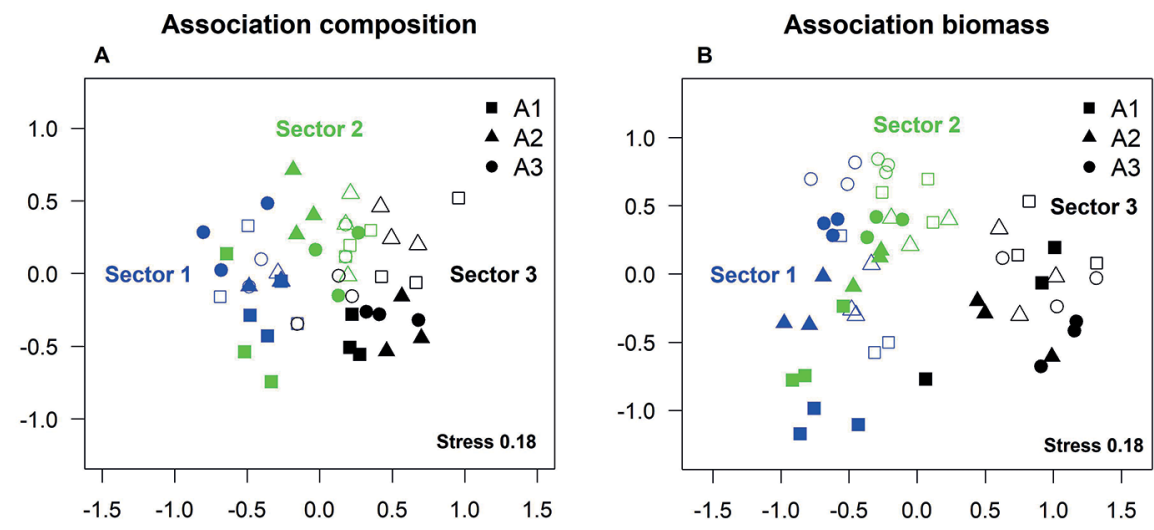

Figure 3. Non-Metric Multidimensional Scaling ordination (nMDS) from association composition (A) and association biomass (B). Markers symbolize each sampling site in each sampling campaign, winter (empty symbols) and summer (filled symbols). Sectors are differentiated by color, blue - Oligohaline sector (Sector 1); green: Mesohaline sector (Sector 2) and black: Euhaline sector (Sector 3). Areas within each sector are differentiated by symbols ( $\mathrm{A} 1$ - square, $\mathrm{A} 2$ - triangle, $\mathrm{A} 3$ - circle). The value stress is reported as an indicator of quality of the scaling.

also changed along the estuarine gradient due to the limited distribution of $C$. caespitos $a$ and the absence of B. montagnei, B. moritziana, B. tenella, B. binderi, $C$. membranacea and $C$. rupestris in the low salinity sector. Other species were present along the entire estuarine gradient, such as $B$. radicans, $B$. calliptera, $B$. pinnata, $C$. leprieurii, $R$. riparium and Microcoleus sp.

At the large spatial scale, there was a tendency of total biomass increase in S3, detected mainly in the summer sampling campaign. This tendency was induced by the biomass of B. montagnei and B. binderi, which were restricted to higher salinity environments and are the largest algae among Bostrychietum. Morphologically, B. binderi has denser cortication than other species, and B. montagnei has up to seven pericentral cells. Therefore, they are able to produce more biomass by area of fixation when at optimum growth conditions compared to the dominant species in other sectors. However, B. binderi distribution was patchy and had high variability among replicates within areas. Association biomass was significantly different among all scales. This indicates that the association biomass may have had the same amount of biomass throughout the estuary, but this biomass is not equally distributed among species at any of the spatial scales. The most abundant species corroborated the uneven biomass pattern of distribution, showing greater variability at small scales. In summary, our hypothesis of biomass increase with higher salinity was not corroborated, reinforcing the need to better understand the small-scale processes inducing the Bostrychietum algae biomass distribution.

The greater variability of Bostrychietum algae at the smaller scale (areas) than large scale (sectors) seemed to be in responce to environmental conditions other than salinity. Even though we tried to standardize the environmental conditions where samples were collected (e.g. same day, same tide, at mangrove fringe, same substrate and sampling height), the areas are subject to other variables not easily correlated to the Bostrychietum algae distribution. First, Bostrychietum algae compete for hard substrates inside mangroves. High canopy density and high shade levels tend to decrease thermal exposure and humidity loss, therefore reducing emersion stress and leading to an increase in algal diversity and biomass (Yokoya et al. 1999, Zhang et al. 2014). Environmental disturbances such as waves, sediment in suspension, availability of nutrients, and other habitat conditions are known to cause variations on small scale (Seangkaew et al. 2016). Finally, we collected algae within a $20 \mathrm{~cm}$ vertical distribution, Bostrychia scorpioides and Catenella caespitosa may show different phenotypes and physiological responses already within a vertical range of $30 \mathrm{~cm}$ (Sánchez de Pedro et al. 2016). In this context, our small-scale sampling analyses (within areas) were limited by a low replicate number (3) and we did not account for all 
Table 3. Summary of statistical analyses applied to biomass data. Association biomass was analyzed with PERMANOVA for which $R^{2}$ values are shown. The total biomass and the biomass of the five most abundant species were analyzed with nested ANOVA. (df: degrees of freedom; MS: mean of squares; F: F-ratio (random nested factor corrected by residuals), R2: correlation, PC\%: percentage of contribution). P. value < alpha level in bold.

\begin{tabular}{|c|c|c|c|c|c|c|c|c|c|c|}
\hline \multirow[b]{2}{*}{ PERMANOVA } & \multicolumn{5}{|c|}{ Winter } & \multicolumn{5}{|c|}{ Summer } \\
\hline & $\mathrm{df}$ & MS & $\mathrm{F}$ & $\mathrm{R}^{2}$ & $P$ & $\mathrm{df}$ & MS & $\mathrm{F}$ & $\mathrm{R}^{2}$ & $P$ \\
\hline \multicolumn{11}{|c|}{ Association biomass } \\
\hline Sector & 2 & 1.31 & 14.92 & 44 & $<0.001$ & 2 & 1.82 & 27.60 & 55 & $<0.001$ \\
\hline Area & 6 & 0.28 & 3.23 & 29 & 0.034 & 6 & 0.28 & 4.34 & 26 & $<0.001$ \\
\hline Residuals & 18 & 0.26 & & 27 & & 18 & 0.66 & & 18 & \\
\hline ANOVA & $\mathrm{df}$ & MS & $\mathrm{F}$ & PC\% & $P$ & $\mathrm{df}$ & MS & $\mathrm{F}$ & PC\% & $P$ \\
\hline \multicolumn{11}{|l|}{ Total biomass } \\
\hline Sector & 2 & 0.31 & 0.32 & 0 & 0.731 & 2 & 125.45 & 4.41 & 37 & 0.066 \\
\hline Area & 6 & 0.96 & 5.46 & 55 & 0.002 & 6 & 85.30 & 2.66 & 27 & 0.050 \\
\hline Residuals & 18 & 0.17 & & 45 & & 18 & 96.19 & & 36 & \\
\hline \multicolumn{11}{|l|}{ B. radicans } \\
\hline Sector & 2 & 0.80 & 5.06 & 29 & 0.051 & 2 & 0.45 & 6.18 & 45 & 0.034 \\
\hline Area & 6 & 0.15 & 3.09 & 25 & 0.029 & 6 & 0.07 & 4.10 & 25 & 0.009 \\
\hline Residuals & 18 & 0.05 & & 46 & & 18 & 0.01 & & 30 & \\
\hline \multicolumn{11}{|l|}{ B. pinnata } \\
\hline Sector & 2 & 0.40 & 0.99 & 8 & 0.422 & 2 & 1.60 & 4.66 & 37 & 0.060 \\
\hline Area & 6 & 0.40 & 2.42 & 42 & 0.068 & 6 & 0.34 & 4.76 & 34 & 0.004 \\
\hline Residuals & 18 & 0.16 & & 50 & & 18 & 0.07 & & 29 & \\
\hline \multicolumn{11}{|l|}{ B. calliptera } \\
\hline Sector & 2 & 0.15 & 0.23 & 0.0 & 0.797 & 2 & 1.97 & 10.32 & 43 & 0.011 \\
\hline Area & 6 & 0.66 & 6.35 & 43 & $<0.001$ & 6 & 0.19 & 2.59 & 18 & 0.054 \\
\hline Residuals & 18 & 0.10 & & 57 & & 18 & 0.07 & & 39 & \\
\hline \multicolumn{11}{|l|}{ B. montagnei } \\
\hline Sector & 2 & 5.72 & 33.43 & 51 & $<0.001$ & 2 & 3.79 & 22.35 & 54 & 0.001 \\
\hline Area & 6 & 0.17 & 4.90 & 31 & 0.003 & 6 & 0.16 & 2.23 & 0 & 0.087 \\
\hline Residuals & 18 & 0.03 & & 18 & & 18 & 0.07 & & 46 & \\
\hline \multicolumn{11}{|l|}{ B. binderi } \\
\hline Sector & 2 & 0.33 & 2.73 & 30 & 0.143 & 2 & 7.41 & 7.58 & 39 & 0.023 \\
\hline Area & 6 & 0.12 & 1.10 & 0 & 0.395 & 6 & 2.93 & 27.96 & 36 & $<0.001$ \\
\hline Residuals & 18 & 0.10 & & 70 & & 18 & 0.01 & & 25 & \\
\hline
\end{tabular}

environmental variables. Therefore, studies including smaller spatial scales appropriately correlated with environmental forces will be necessary for a better understanding of the variation within areas.

The sampling design adopted does not allow for the evaluation of temporal variations due to the lack of seasonal replication. However, seasonal variations in the composition and total biomass of Bostrychietum have already been reported in several studies (Bouzon \& Ouriques 1999; Melville et al. 2005; Zhang et al. 2014; Billah et al. 2016). In this sense, seasonal variability may explain the differences or inconsistencies in Bostrychietum algae responses among sampling campaigns, such as for the biomass of B. calliptera. The Paranaguá Bay climate has a typical rainy season (late spring to most of the summer) and a dry season (late autumn to late winter) (Lana et al., 2001), which could affect the vertical distribution 

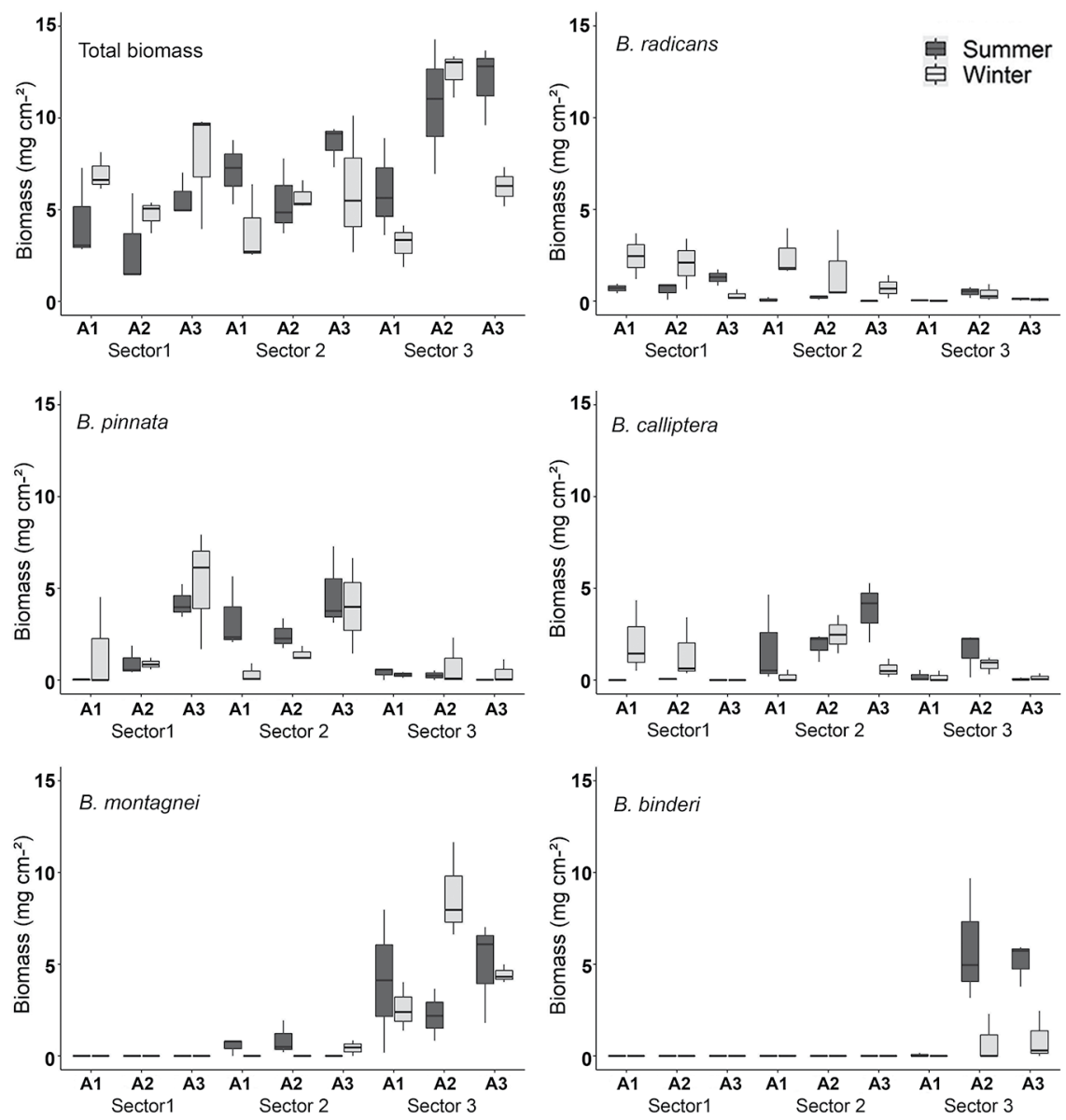

Figure 4. Box plots of total biomass and biomass data of the five most abundant species along the estuarine gradient. Dry weight values given in $\mathrm{mg} \mathrm{cm}^{-2}$.

and photosynthesis rate and thus the growth and biomass accumulation of Bostrychia and Caloglossa (Fernandes and Alves 2011. Peña et al., 1999).

Macroalgae are well adapted to salinity variation (Bisson \& Kirst 1995, Karsten 2012). For example, Bostrychia species are known to maintain photosynthetic rates at salinities ranging from 5 to 45 , and they can tolerate exposure to freshwater for up to two days without experiencing permanent damage (Mann and Steinke 1988). In addition, B. radicans, $B$. calliptera and $B$. pinnata have adaptations to adjust the intracellular osmotic response to variations in salinity (Karsten et al. 1996)one of the citric acid cycle (malate dehydrogenase, MDH. Contrary to expectations, Catenella caespitosa was restricted to the oligohaline sector. Catenella has physiological adaptations to cope with salinity variation (Karsten et al. 1996) one of the citric acid cycle (malate dehydrogenase,
$\mathrm{MDH}$ and Catenella caespitosa was found in the Adriatic Sea (salinity 38) (Battelli 2004) and close to river mouths (salinity 20) (Pedroche et al. 1995, Sánchez de Pedro et al. 2016). Other factors must have affected its distribution limited to the low salinity sector of Paranaguá Bay, such as competition with Bostrychia montagnei and B. binderi. The variability of Bostrychietum algae among areas emphasizes the need for additional studies regarding environmental forces acting on smaller scales, including biological interactions among species, for a better understanding of the dynamics of Bostrychietum algae.

Differences in the salinity tolerance of the Bostrychietum algae and their cosmopolitan distribution could provide applications regarding their use as mangrove environmental biomonitors (Melville and Pulkownik 2006, 2007). AlgaeBase (Guiry and Guiry, 2016) data show that B. calliptera, B. montagnei, 
B. moritziana and B. radicans are present along the entire Brazilian coast and have a broad global distribution, generally accompanying the geographical limits of mangroves. Among those species, $B$. radicans and $B$. pinnata were present along the entire salinity gradient in both campaigns in Paranaguá Bay. This makes both species suitable for use as environmental biomonitors.

\section{CONCLUSION}

The estuarine horizontal salinity gradient will affect the distribution of a few species of Bostrychietum, such as $B$. montagnei, B. binderi and $B$. tenella, which were commonly identified in the higher salinity sector. Therefore, higher richness was observed in higher salinity regions, partially corroborating our hypothesis. However, the salinity gradient has no apparent or linear effect on the total biomass along the estuary. Overall, we identified that salinity is not the main driver of the distribution of Bostrychietum algae; conversely, the main variations were found on the small scale (areas). Understanding the small scale, heterogeneous variability in the distribution of mangrove algae will demand a finer hierarchical sampling design and monitoring of environmental variables.

\section{ACKNOWLEDGMENTS}

This work was supported by Conselho Nacional de Desenvolvimento Científico e Tecnológico (CNPq) through a Scientific Initiation Scholarship for the first author. The Centro de Estudos do Mar from Universidade Federal do Paraná (UFPR) provided the infrastructure and logistical support to execute the project. We are grateful to all our lab coworkers who gave us support and all the needed help.

\section{AUTHOR CONTRIBUTIONS}

I.R.W.M.: Conceptualization; Formal analysis; Investigation; Writing - original draft; Writing review \& editing.

P.C.L.: Conceptualization; Resources; Supervision; Writing - review \& editing.

\section{REFERENCES}

ALVES, A. M., MOURA, C. W. N., ALVES G. L. \& GESTINARI, L. M. S. 2009. Os gêneros Chaetomorpha Kütz. nom. cons. e Rhizoclonium Kütz. (Chlorophyta) do litoral do Estado da Bahia, Brasil. Revista Brasileira de Botânica, 32(3), 545570.

ARBIZU, P. M. 2017. pairwiseAdonis: pairwise multilevel comparison using Adonis. R package version 0.4 [online]. San Francisco: GitHub, Inc. Available at: https://github.com/pmartinezarbizu/pairwiseAdonis [Accessed: 2020 Dec 02].

BATTELLI, C. 2004. Phytocoenological study of the Catenella caespitosa (Withering) L.M. Irvine (Gigartinales, Rhodophyceae) community from the Slovenian coast, northern Adriatic Sea. Acta Adriatica, 45(2), 121-130.

BATES, D., MAECHLER, M., BOLKER, B. \& WALKER, S. 2015. Fitting linear mixed-effects models using Ime4. Journal of Statistical Software, 67(1), 1-48.

BILLAH, M. M., KAMAL, A. H. M., IDRIS, M. H. B. \& ISMAIL, J. B. 2016. Seasonal variation in the occurrence and abundance of mangrove macroalgae in a Malaysian estuary. Cryptogamie Algologie, 37(2), 109-120.

BISSON, M. A. \& KIRST, G. O. 1995. Osmotic acclimation and turgor pressure regulation in algae. Naturwissenschaften 82, 461-471.

BOUZON, Z. L. \& OURIQUES, L. C. 1999. Occurrence and distribution of Bostrychia and Caloglossa (Rhodophyta, Ceramiales) in the Ratones River mangrove, Florianópolis-SC-Brazil. Insula, 28, 43-52.

CLARKE, K. R. 1993. Non-parametric multivariate analyses of changes in community structure. Australian Journal of Ecology, 18(1), 117-143.

COLLADO-VIDES, L. \& WEST, J. A. 1996. Bostrychia calliptera (Montagne) Montagne (Rhodomelaceae, Rhodophyta), registro nuevo para el centro del Golfo de México. Ciencias Marinas, 22(2), 47-55.

CORDEIRO-MARINO, M. 1978. Rodofíceas bentônicas matinhas do Estado de Santa Catarina. Rickia, 7, 1-243.

CUNHA, S. R. \& COSTA, C. S. B. 2002. Gradientes de salinidade e freqüência de alagamento como determinantes da distribuição e biomassa de macroalgas associadas a troncos de manguezais na Baía de Babitonga, SC. Notas Técnicas Facimar, 6(1), 93-102.

CUNHA, S. R., NASCIMENTO, J. R., LIMA, G. B., ZACHARJASIEWICZ, G., CRESTANI, D. E. V., MAFRA JUNIOR, L. L., PAZETO, F. D. SANT'ANNA, F. \& COSTA, C. S. B. 1999. Distribuição e biomassa de macroalgas em um manguezal da Baía da Babitonga, SC: resultados preliminares. Notas Técnicas Facimar, 3(1), 1-15.

DAWES, C., SIAR, K. \& MARLETT, D. 1999. Mangrove structure, litter and macroalgal productivity in a northern-most forest of Florida. Mangroves and Salt Marshes, 3, 259-267.

FERNANDES, M. E. B. \& ALVES, E. F. S. 2011. Occurrence and distribution of macroalgae (Rhodophyta) associated with mangroves on the Ajuruteua Peninsula, Bragança, Pará, Brazil. UAKARI, 7(2), 35-42. 
FERNANDES, M. E. B., SILVA, E. S., LIMA, J. F., VARELA, E. S., HERCOS, A. P., FERNANDES, C. M., ARRUDA, C. C. B., GOMES, G., SANTOS, H., SOARES, C. \& SARAIVA, R. M. 2005. Distribuição espacial das macroalgas associadas às florestas de mangue na península de Ajuruteua Bragança-Pará. Boletim do Laboratório de Hidrobiologia, 18(1), 11-17.

GUIRY, M. D. \& GUIRY, G. M. 2021. AlgaeBase. World-wide electronic publication. Galway: National University of Ireland.

HADLICH, R. M. \& BOUZON, Z. L. 1985. Contribuição ao levantamento taxonômico das algas marinhas do mangue de Itacorubi - Florianópolis - Ilha de Santa Catarina - Brasil - II Rhodophyta. Ínsula, 15, 89-116.

HEITHAUS, E. R., HEITHAUS, P. A., HEITHAUS, M. R., BURKHOLDER, D. \& LAYMAN, C. A. 2011. Trophic dynamics in a relatively pristine subtropical fringing mangrove community. Marine Ecology Progress Series, 428, 49-61.

HILL, R., BELLGROVE, A., MACREADIE, P. I., PETROU, K., BEARDALL, J., STEVEN, A. \& RALPH, P. J. 2015. Can macroalgae contribute to blue carbon? An Australian perspective. Limnology and Oceanography, 60(5), 1689-1706.

HORNE, J. K. \& SCHNEIDER, D. V. 1995. Spatial variance in ecology. OIKOS, 74, 18-26.

JOLY, A. B. 1957. Contribuição ao conhecimento da flora ficológica marinha da Baía de Santos e arredores. Boletim da Faculdade de Filosofia, Ciências e Letras - USP, 14, 199.

JOLY, A. B. 1965. Flora marinha do litoral norte do Estado de São Paulo e regiões circunvizinhas. Separata do Boletim n 294. Boletim da Faculdade de Filosofia, Ciências e Letras - USP, 21, 267.

JOLY, A. B. 1967. Gêneros de algas marinhas da costa Atlântica Latino-Americana. São Paulo: EDUSP.

KARSTEN, U. 2012. Seaweed acclimation to salinity and desiccation stress. In: WIENCKE, C. \& BISCHOF, K. (eds.). Seaweed biology. Heidelberg: Springer-Verlag, pp. 87-107.

KARSTEN, U., BARROW, K. D., NIXDORF, O. \& KING, R. J. 1996. The compability with enzyme activity of unusual organic osmolytes from mangrove red algae. Australian Journal of Plant Physiology, 23(5), 577-582.

KARSTEN, U., WEST, J. A., MOSTAERT, A. S., KING, R. J., BARROW, K. D. \& KIRST, G. O. 1992. Mannitol in the red algal genus Caloglossa (Harvey) J. Agardh. Journal of Plant Physiology, 140, 292-297.

KIECKBUSCH, D. K., KOCH, M. S., SERAFY, J. E. \& ANDERSON, W. T. 2004. Trophic linkages among primary producers and consumers in fringing mangroves of subtropical lagoons. Bulletin of Marine Science, 74(2), 271-285.

LAMY, T., REED, D. C., RASSWEILER, A., SIEGEL, D. A., KUI, L., BELL, T. W., SIMONS, R. D. \& MILLER, R. J. 2018. Scale-specific drivers of kelp forest communities. Oecologia, 186(1), 217-233.

LANA, P. C., MARONE, E., LOPES, R. M. \& MACHADO, E. C. 2001. The subtropical estuarine complex of Paranaguá Bay, Brazil. In: SEELIGER, U. \& KJERFVE B. (eds.). Coastal marine ecosystem of Latin America. Ecological Studies (Analysis and Synthesis). Berlin: Springer, pp. 131-145.

MANN, F. D. \& STEINKE, T. D. 1988. Photosynthetic and respiratory responses of the mangrove-associated red algae, Bostrychia radicans and Caloglossa leprieurii. South African Journal of Botany, 54(3), 203-207.
MARONE, E., MACHADO, E. C., LOPES, R. M. \& SILVA, E. T. 2005. Land-ocean fluxes in the Paranaguá Bay estuarine system, southern Brazil. Brazilian Journal of Oceanography, 53(3-4), 169-181.

MCGARIGAL, K., WAN, H. Y., ZELLER, K. A., TIMM, B. C. \& CUSHMAN, S. A. 2016. Multi-scale habitat selection modeling: a review and outlook. Landscape Ecology, 31, 1161-1175.

MELVILLE, F. \& PULKOWNIK, A. 2006. Investigation of mangrove macroalgae as bioindicators of estuarine contamination. Marine Pollution Bulletin, 52(10), 1260-1269.

MELVILLE, F. \& PULKOWNIK, A. 2007. Seasonal and spatial variation in the distribution of mangrove macroalgae in the Clyde River, Australia. Estuarine Coastal and Shelf Science, 71(3-4), 683-690.

MELVILLE, F., PULKOWNIK, A. \& BURCHETT, M. 2005. Zonal and seasonal variation in the distribution and abundance of mangrove macroalgae in the Parramatta River, Australia. Estuarine Coastal and Shelf Science, 64(2-3), 267-276.

OKSANEN, L., BLANCHET, F. G., FRIENDLY, M., KINDT, R., LEGENDRE, P., MCGLINN, D., MINCHIN, P. R., O'HARA, R. B., SIMPSON, G. L., SOLYMOS, P., STEVENS, M. H. H., SZOECS, E. \& WAGNER, H. 2020. Vegan: Community Ecology Package. R package version 2.5-7 [online]. US: Scientific Research Publishing, Inc. Available at: https://CRAN.R-project.org/package=vegan [Accessed: 2020 Dec 02].

PEDROCHE, F. E., WEST, J. A., ZUCCARELLO, G. C., SENTIES, A. G. \& KARSTEN, U. 1995. Marine red algae of the mangroves in Southern Pacific Mexico and Pacific Guatemala. Botanica Marina, 38, 111-119.

PEÑA, E. J., ZINGMARK, R. \& NIETCH, C. 1999. Comparative photosynthesis of two species of intertidal epiphytic macroalgae on mangrove roots during submersion and emersion. Journal of Phycology, 35(6), 1206-1214.

PEÑA-SALAMANCA, E. J. 2008. Dinámica espacial y temporal de la biomasa algal asociada a las raíces de mangle en la Bahía de Buenaventura, Costa Pacífica de Colombia. Boletín de Investigaciones Marinas y Costeras, 37(2), 55-70.

POST, E. 1936. Systematische und pflanzengeographische Notizen zur Bostrychia-Caloglossa Assoziation. Revue Algologie, 9, 1-84.

$\mathrm{R}$ CORE TEAM. 2020. $R$ : A language and environment for statistical computing [online]. Vienna: R Foundation for Statistical Computing. Available at: https://www.R-project.org/ [Accessed: 2021 Jan 15].

REINE, W. F. P. \& MARCHAND, R. P. 1983. Red algae found on European salt-marshes. II. Catenella caespitosa (Rhabdoniaceae). Aquatic Botany, 15, 287-298.

SÁNCHEZ DE PEDRO, R. S., KARSTEN, U., NIELL, F. X. \& CARMONA, R. 2016. Intraspecific phenotypic variation in two estuarine rhodophytes across their intertidal zonation. Marine Biology, 163(10), 220-234.

SANDRINI-NETO, L. \& CAMARGO, M. G. 2020. GAD: an R package for ANOVA designs from general principles [online]. US: CRAN - R Project. Available at: http://cran.r-project.org/web/packages/GAD [Accessed: 2020 Dec 02].

SANDRINI-NETO, L. \& LANA, P. C. 2012. Distribution patterns of the crab Ucides cordatus (Brachyura, Ucididae) at different spatial scales in subtropical mangroves of Paranaguá Bay (southern Brazil). Helgoland Marine Research, 66, 167-174. 
SEANGKAEW, J., BOVONSOMBUT, S. \& PEERAPORNPISAL, Y. 2016. Species diversity and distribution of mangrove-associated red alga Bostrychia (Rhodomelaceae, Rhodophyta) from southern Thailand. International Journal of Applied Environmental Sciences, 11(1), 55-71.

SLUIMAN, H. J. 1978. A note on Bostrychia scorpioides (Hudson) Montagne ex Kützing and B. montagnei harvey (Rhodomelaceae, Rhodophyta). Blumea, 24, 301-305.

SPIER, D., GERUM, H. L. N., NOERNBERG, M. A. \& LANA, P. C. 2016. Flood regime as a driver of the distribution of mangrove and salt marsh species in a subtropical estuary. Journal of Marine Systems, 161, 11-25.

STEINKE, T. D., LUBKE, R. A. \& WARD, C. J. 2003. The distribution of algae epiphytic on pneumatophores of the mangrove, Avicennia marina, at different salinities in the Kosi System. South African Journal of Botany, 69(4), 546-554.

UNDERWOOD, A. J. 1997. Experiments in ecology. Their logical design and interpretation using analysis of variance. Melbourne: Cambridge University Press.

VIEIRA, E. A., FILGUEIRAS, H. R., BUENO, M., LEITE, F. P. P. \& DIAS, G. M. 2018. Co-occurring morphologically distinct algae support a diverse associated fauna in the intertidal zone of Araçá Bay, Brazil. Biota Neotropica, 18(1), 1-8.
WESSEL, P. \& SMITH, W. H. F. 1996 A global self-consistent, hierarchical, high-resolution shoreline database. Journal Geophysics Research, 101(B4), 8741-8743. Available at: https:// www.ngdc.noaa.gov/mgg/shorelines/ [Accessed: 2019 Nov 03].

WEST, J. A., HOMMERSAND, M. \& ZUCCARELLO, G. C. 2001. Morphology and reproduction of Bostrychia pinnata (Rhodomelaceae, Ceramiales) in laboratory culture. Phycologial Research. 49, 285-297.

YARISH, C. \& EDWARDS, P. 1982. A field and cultural investigation of the horizontal and seasonal distribution of estuarine red algae of New Jersey. Phycologia, 21(2), 112-124.

YOKOYA, N. S., PLASTINO, E. M., BRAGA, M. R. A., FUJII, M. T., CORDEIRO-MARINO, M., ESTON, V. R. \& HARARI, J. 1999. Temporal and spatial variations in the structure of macroalgal communities associated with mangrove trees of Ilha do Cardoso, São Paulo state, Brazil. Revista Brasileira de Botânica, 22(2), 195-204.

ZHANG, Y., LI, Y., SHI, F., SUN, X. \& LIN, G. 2014. Seasonal and spatial variation in species diversity, abundance, and element accumulation capacities of macroalgae in mangrove forests of Zhanjiang, China. Acta Oceanologica Sinica, 33(8), 73-82. 